\title{
Synthesis of deuterated dextromethorphan derivatives
}

\author{
Hedvig Bölcskei, * Marianna Mák, Ferencz Dravecz, and \\ György Domány
}

Gedeon Richter Plc., Budapest, 10. POB 27. H-1475 Hungary

E-mail: h.bolcskei@richter.hu

\section{Dedicated to Professor Csaba Szántay on the occasion of his 80th birthday}

\begin{abstract}
Dextromethorphan is a widely used NMDA receptor antagonist and sodium channel blocker. Deuterated dextromethorphan and dextrorphan were synthesized via the N-desmethyldextromethorphan intermediate for pharmacokinetic study.
\end{abstract}

Keywords: Deuteration, dextromethorphan, dextrorphan, N-demethylation, methylation

\section{Introduction}

Dextromethorphan $\mathbf{1}$ is widely used as a cough suppressant. ${ }^{1}$ It is an antagonist of the $N$-methylD-aspartate (NMDA) receptor and an agonist at sigma receptors. ${ }^{1}$ Dextromethorphan 1 showed anticonvulsant activity and neuroprotective effect in cerebral ischemia. ${ }^{2}$ It was studied for the treatment of pain and Parkinson's disease. ${ }^{3}$ The main metabolite of $\mathbf{1}$ is dextrorphan ${ }^{1} \mathbf{2}$, which is also an antagonist of the NMDA receptor. It was studied as a neuroprotective agent in the management of stroke. ${ }^{4}$

Dextromethorphan is often used as a component of drug combinations. Recently Richter patented the finding that $\mathbf{1}$ increased the effectiveness of the voltage gated sodium channel blocker tolperisone in animal models of various central nervous system disorders. ${ }^{5}$ The mechanism of this effect is not quite clear, but possibly the serotonin uptake blocking effect of $\mathbf{1}$ plays a role. 


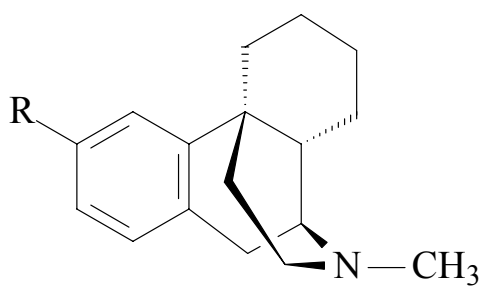

1 Dextromethorphan $\mathrm{R}=\mathrm{OCH}_{3}$,

2 Dextrorphan $\mathrm{R}=\mathrm{OH}$

$3 \mathrm{R}=\mathrm{OCD}_{3}$ derivative of $\mathbf{1}$

Figure 1. Dextromethorphan, dextrorphan and $\mathrm{CD}_{3} \mathrm{O}$-derivative of dextromethorphan.

\section{Results and Discussion}

For pharmacokinetic studies we needed deuterated dextromethorphan and dextrorphan derivatives with three or more deuterium atoms. The isotopic enrichment and purity were required to be over $95 \%$ and $98 \%$, respectively. The $\mathrm{CD}_{3} \mathrm{O}$-derivative of dextromethorphan 3 is a known compound, but its synthesis was not published. ${ }^{6}$ Through N-desmethyl-dextromethorphan 4 intermediate we planned to prepare the $\mathrm{N}-\mathrm{CD}_{3}$-derivative of dextromethorphan 5 which can be an intermediate of $\mathrm{N}-\mathrm{CD}_{3}$-dextrorphan $\mathbf{6}$ in the following synthetic route (Scheme 1).
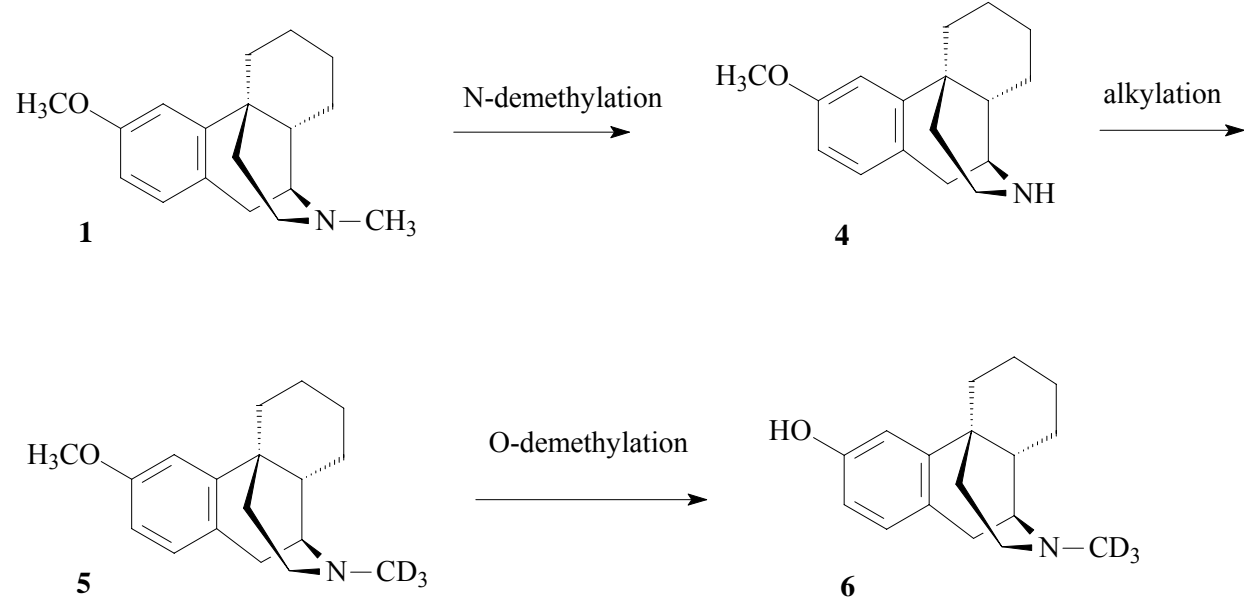

6

Scheme 1. The planned synthetic route.

$\mathrm{N}$-Demethylation is an important question in the chemistry of alkaloids e.g. morphine alkaloids and morphinane derivatives. Several methods for it are known. The traditional method is the von Braun reaction ${ }^{7}$ which is not suggested because of the toxicity of the reagent (cyanogen bromide). Photochemical N-demethylation is a quite special reaction with moderate yield. ${ }^{8}$ The yield of the sodium sulfide or potassium thioacetate method is not high enough and 
undesired side reactions could be noticed. ${ }^{9} \mathrm{~N}$-demethylation of the tertiary amine alkaloids e.g. certain opiate alkaloids using the non-classical Polonovski reaction resulted in the product in moderate yield only. ${ }^{10}$

Nowadays the chloroformate esters (methyl, ${ }^{11}$ ethyl, ${ }^{12-14}$ phenyl, ${ }^{13,14}$ benzyl, ${ }^{14}$ etc.) are preferred rather than the above mentioned reagents. We applied Peet's method ${ }^{15}$ to $\mathrm{N}$ demethylation under slightly modified conditions (Scheme 2). The crude trichloroethyl carbomate derivative 7 contained a small amount of starting material $\mathbf{1}$, which can cause an impurity of the end-product. Purification by column chromatography resulted in the trichloroethyl carbomate in high quality (HPLC: $>99 \%$ purity). The trichloroethoxy carbonyl group was removed by zinc in acetic acid. From the isolated zinc tetraacetate salt $\mathbf{8}$ the free base $\mathrm{N}$-desmethyl-dextromethorphan $\mathbf{4}$ was gained smoothly by treatment with sodium hydroxide.

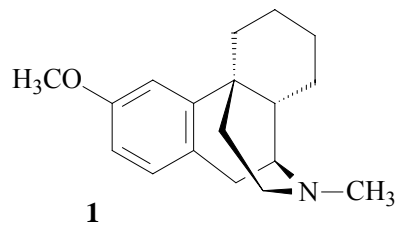

1 toluene

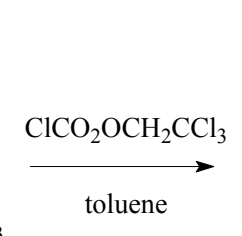

$\mathrm{H}_{3} \mathrm{CO}$

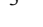

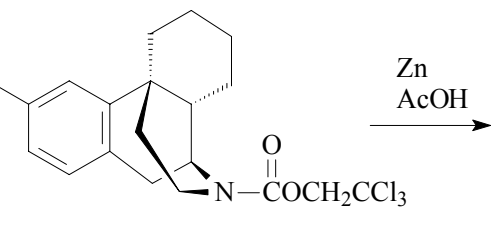

7

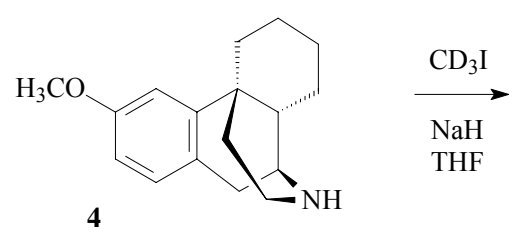

8
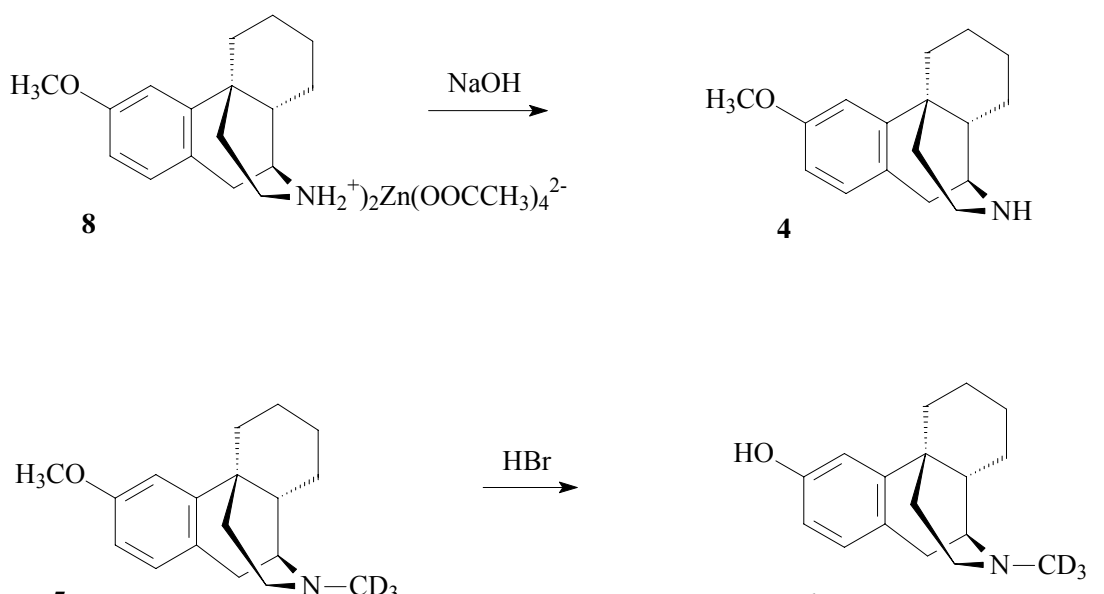

6
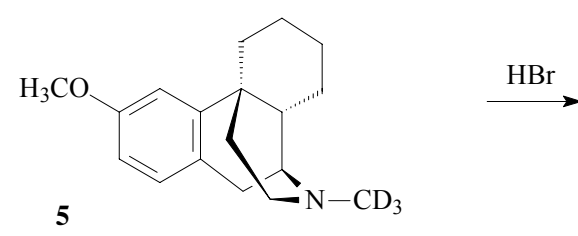

Scheme 2. Synthesis of N-CD - -dextromethorphan 5 and N-CD ${ }_{3}$-dextrorphan 6.

Methylation of N-desmethyl-dextromethorphan 4 with iodomethane- $\mathrm{d}_{3}$ was the crucial step in our synthetic work. At first the usual methods were tested. ${ }^{16,17}$ Using potassium hydroxide in dimethylsulfoxide the conversion was moderate: 70-72\%. Modifying the conditions (sodium hydroxide, toluene, tetrabutylammonium bromide, potassium carbonate) one compound (Mw: 285) was obtained with $60 \%$ conversion. In the presence of potassium carbonate in dipolaraprotic solvent, e.g. acetonitrile or DMF, the conversion was between 93-95\% according to GCMS results. The quaternary salt was also obtained which is disadvantageous because it can be 
easily transformed into a rearranged product. ${ }^{18}$ In the presence of sodium hydride ${ }^{19}$ in tetrahydrofuran the conversion of the methylation was more than $95 \%$.

The most common reagents for O-demethylation are boron tribromide or hydrogen bromide. Both methods were studied. The latter transformed easily the $\mathrm{N}$ - $\mathrm{CD}_{3}$-derivative of dextromethorphan into the corresponding $\mathrm{N}-\mathrm{CD}_{3}$-dextrorphan.

Scheme 2 summarizes our synthetic pathway.

The quality of our $\mathrm{N}-\mathrm{CD}_{3}$-derivative of dextromethorphan 5 and $\mathrm{N}-\mathrm{CD}_{3}$-dextrorphan 6 was checked by GC-MS, HPLC, NMR and MS measurements. The purity of the obtained $\mathrm{N}_{-} \mathrm{CD}_{3}$ dextromethorphan was $>99 \%$ by HPLC, and $97-98 \%$ by GC-MS. The GC-MS technique allowed to detect the $\mathrm{N}-\mathrm{CH}, \mathrm{N}-\mathrm{CH}_{2}$, and $\mathrm{N}-\mathrm{CH}_{3}$ contamination too.

The NMR spectrum of dextromethorphan hydrobromide showed a complex diastereomeric mixture because of $\alpha, \beta$-protonation, which makes it difficult to determine possible $\mathrm{N}-\mathrm{CH}_{3}, \mathrm{~N}$ $\mathrm{CH}_{2} \mathrm{D}$ and $\mathrm{N}-\mathrm{CHD}_{2}$ contamination. Figure 2 shows the ${ }^{1} \mathrm{H}$ NMR spectrum of the commercially available (Sigma-Aldrich) dextromethorphan hydrobromide.

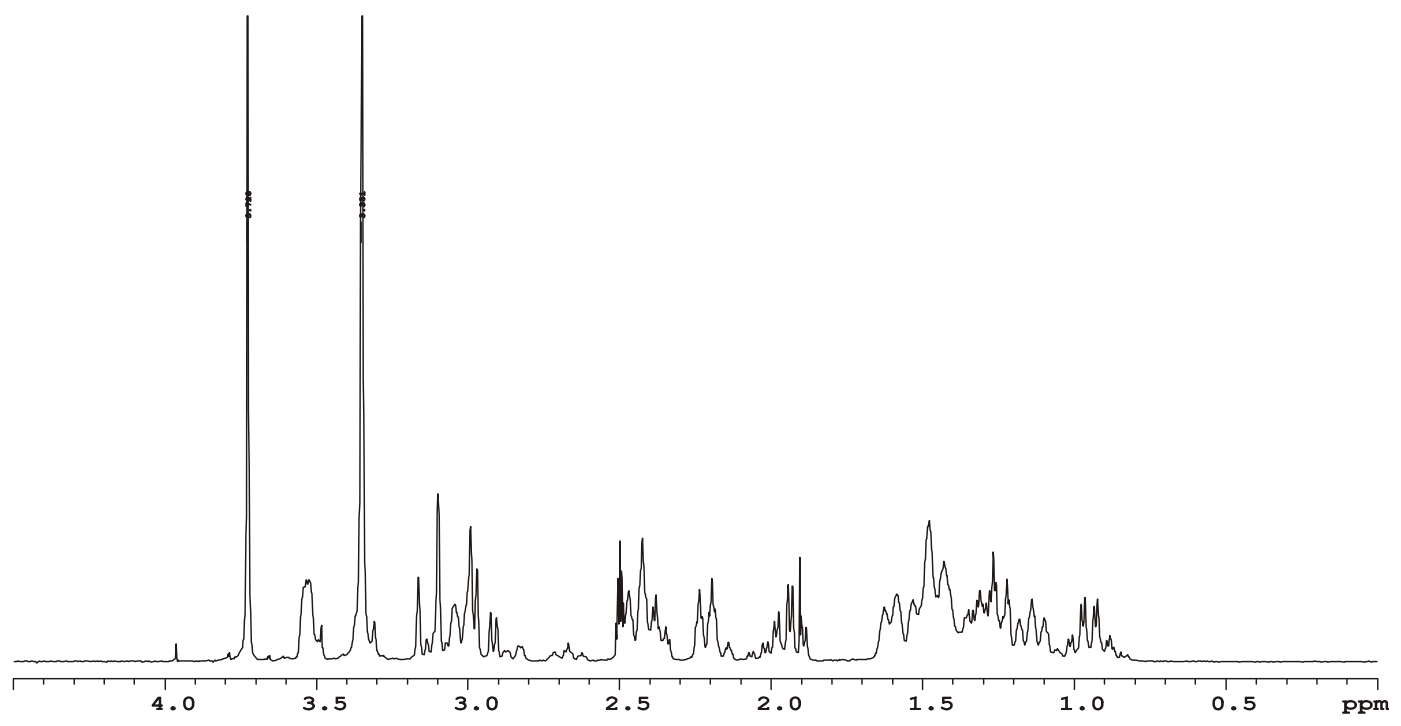

Figure 2. Partial ${ }^{1}$ NMR spectrum of dextromethorphan hydrobromide monohydrate (Sigma D2531 ) in DMSO- $\mathrm{d}_{6}$ showing the aliphatic chemical shift region.

It is more advantageous to study the spectrum of the corresponding base, which is less ambiguous. Figure 3 shows the ${ }^{1} \mathrm{H}$ NMR spectrum of dextrorphan base 2 prepared from dextromethorphan 1 hydrobromide monohydrate (Sigma) by treatment with hydrogen bromide followed with aqueous ammonia. The N-methyl peak can be seen at $\sim 2.3 \mathrm{ppm}$ in DMSO- $\mathrm{d}_{6}$. 


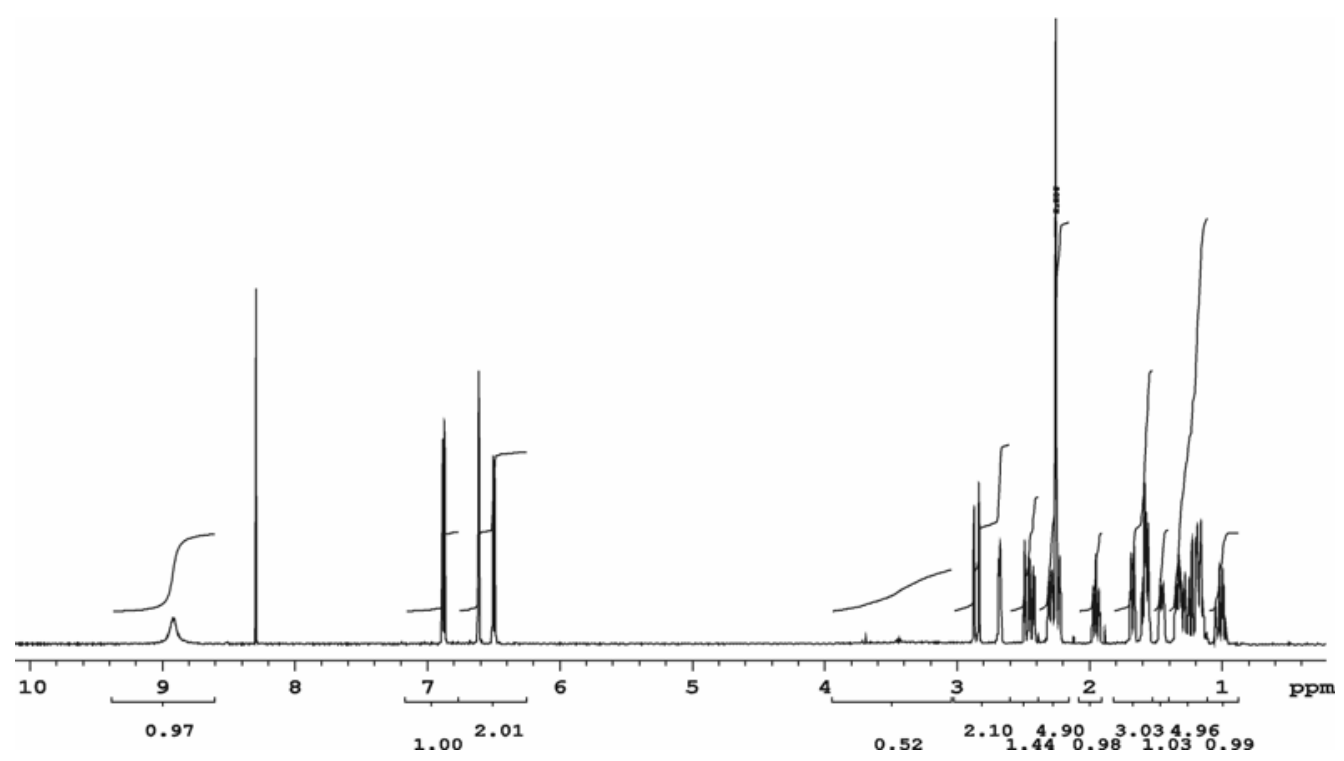

Figure 3. ${ }^{1} \mathrm{H}$ NMR spectrum of dextrorphan base reference compound in DMSO-d $\mathrm{d}_{6}$.

A simpler way to obtain the basic forms of these compounds is to dissolve them in a proper

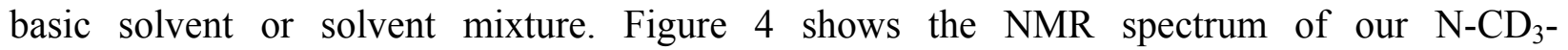
dextromethorphan $\mathrm{HCl}$ salt in pyridine- $\mathrm{d}_{6}: \mathrm{D}_{2} \mathrm{O}=1: 2$ mixture (Figure 4 lower spectrum). When adding dextromethorphan to the sample, the peak at $\sim 2.9 \mathrm{ppm}$ increased (Figure 4 upper spectrum), which belongs to the $\mathrm{N}-\mathrm{CH}_{3}$ group. Integration of this peak showed that the $\mathrm{N}-\mathrm{CH}_{3}$ contamination is smaller than $5 \%$.

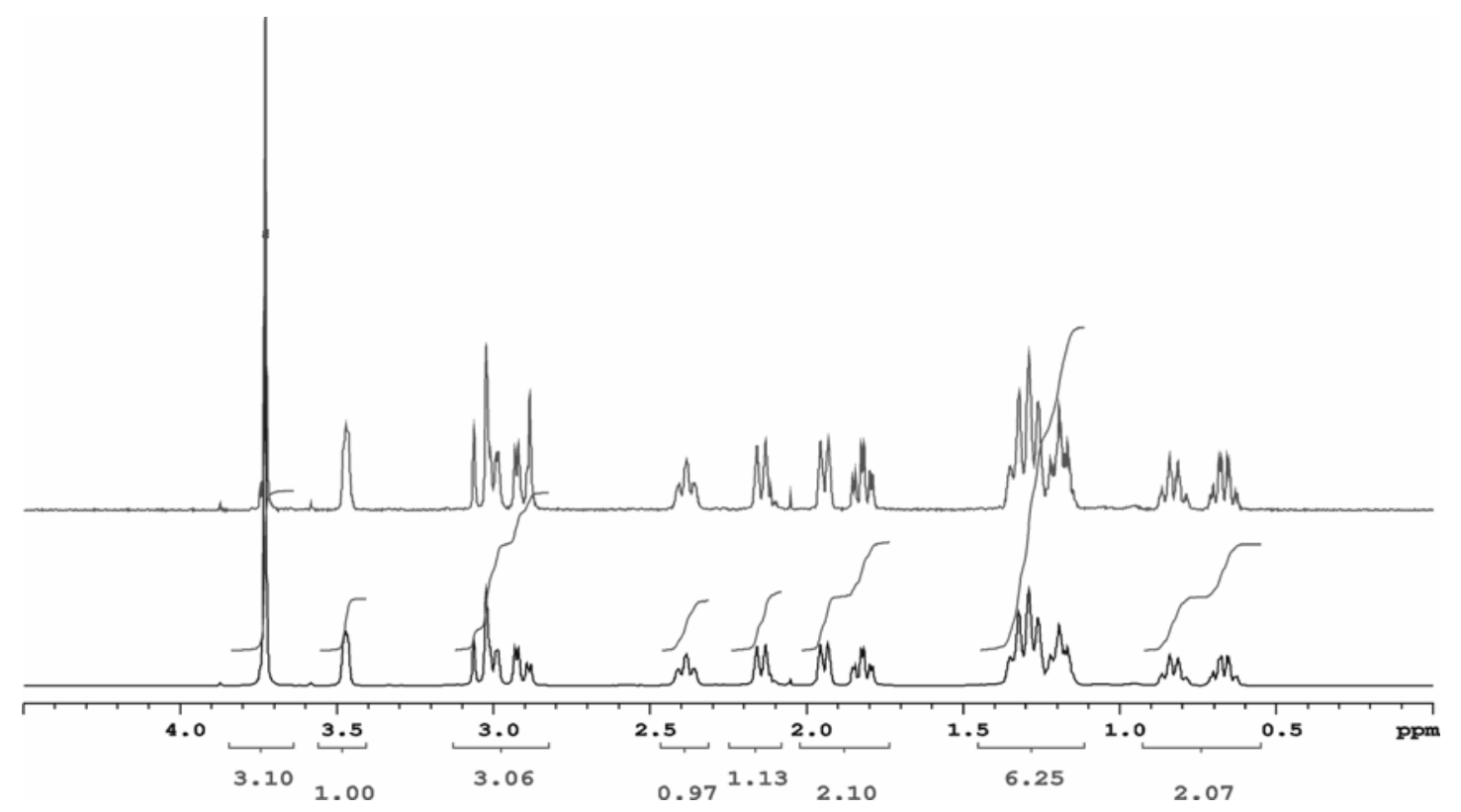

Figure 4. $\mathrm{NMR}$ spectra of $\mathrm{N}-\mathrm{CD}_{3}$-dextromethorphan $\mathrm{HCl}$ (bottom) and the spectrum used for standard addition (top) in pyridine- $\mathrm{d}_{5}: \mathrm{D}_{2} \mathrm{O}=1: 2$ solvent mixture. 
Our $\mathrm{N}-\mathrm{CD}_{3}$-dextrorphan samples were studied in a similar way. Adding dextrorphan hydrogen chloride salt to the sample in the NMR tube, $\mathrm{N}-\mathrm{CH}_{3}$ signal at $\sim 2.3 \mathrm{ppm}$ increased (Figure 5 above spectrum). After integration of this peak in the spectrum of our $\mathrm{N}-\mathrm{CD}_{3}$ dextrorphan sample it became evident that the rest of the $\mathrm{N}-\mathrm{CH}_{3}$ protons was $<5 \%$ (Figure 5 upper spectrum).

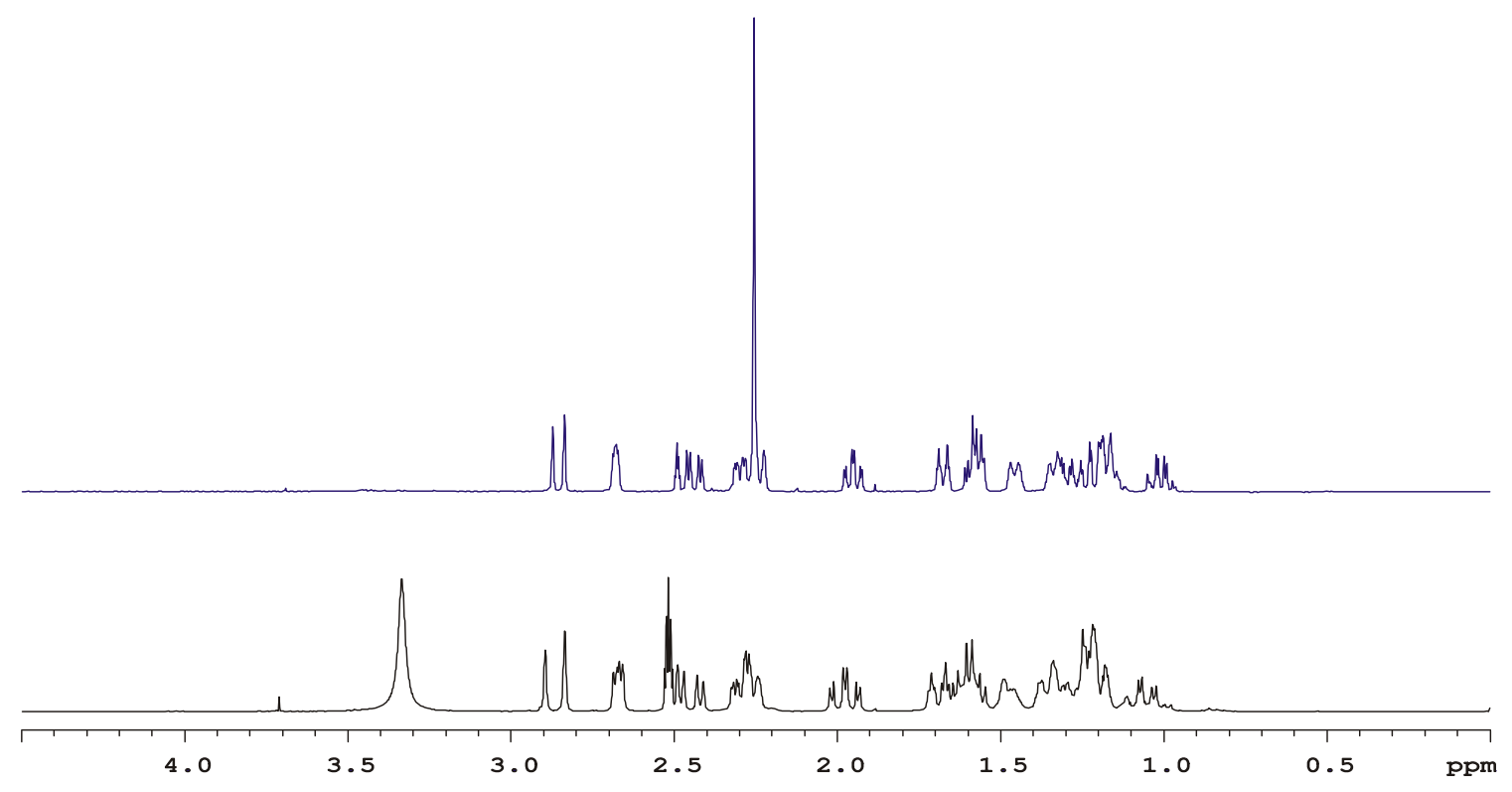

Figure 5. $\mathrm{NMR}$ spectra of $\mathrm{N}-\mathrm{CH}_{3}$-dextrorphan $\mathrm{HCl}$ reference (top), and $\mathrm{N}-\mathrm{CD}_{3}$-dextrorphan $\mathrm{HCl}$ (bottom) in DMSO-d 6 .

The FAB MS spectrum of the commercially available dextromethorphan 1 hydrobromide monohydrate (Sigma D2351) is characterized by an intense protonated molecular ion at $\mathrm{m} / \mathrm{z}$ $\mathrm{MH}^{+}=272$ and $\mathrm{M}-\mathrm{H}^{+}=270(\sim 8 \%)$. The $\mathrm{M}-2 \mathrm{H}^{+}=269$ peak could not be detected (Figure 6$)$. 


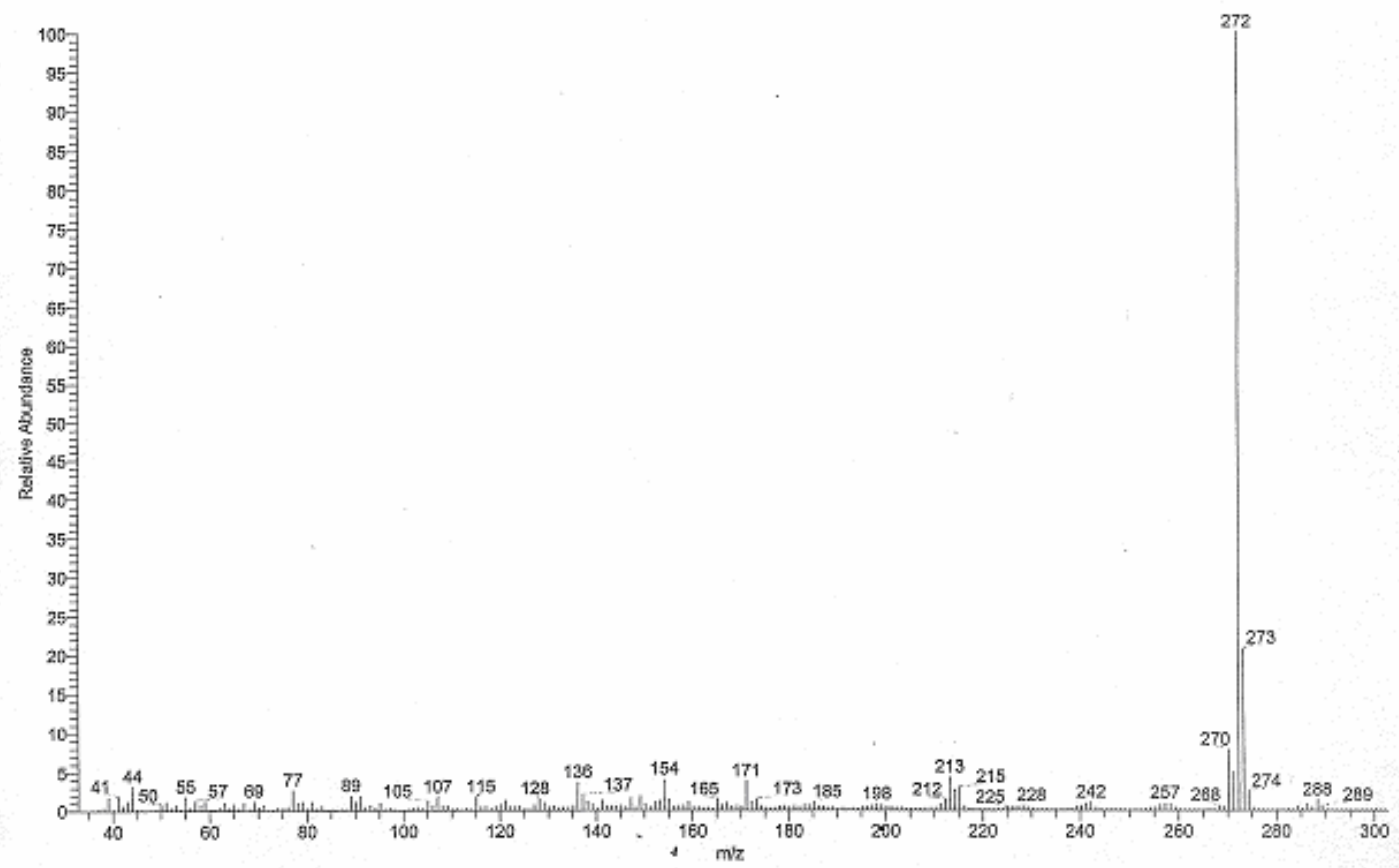

Figure 6. FAB MS spectrum of dextromethorphan hydrobromide monohydrate (Sigma D2351).

The FAB mass spectrum of the stable isotope labeled analog $\mathrm{N}-\mathrm{CD}_{3}$-dextromethorphan hydrochloride salt was dominated by peaks $\mathrm{m} / \mathrm{z} \mathrm{M}_{1} \mathrm{H}^{+}=275$ and $\mathrm{M}_{1}-\mathrm{H}^{+}=273$ due to the mass differences (Figure 7). The $\mathrm{M}_{2} \mathrm{H}^{+}=272$ contamination was $\sim 2 \%$.

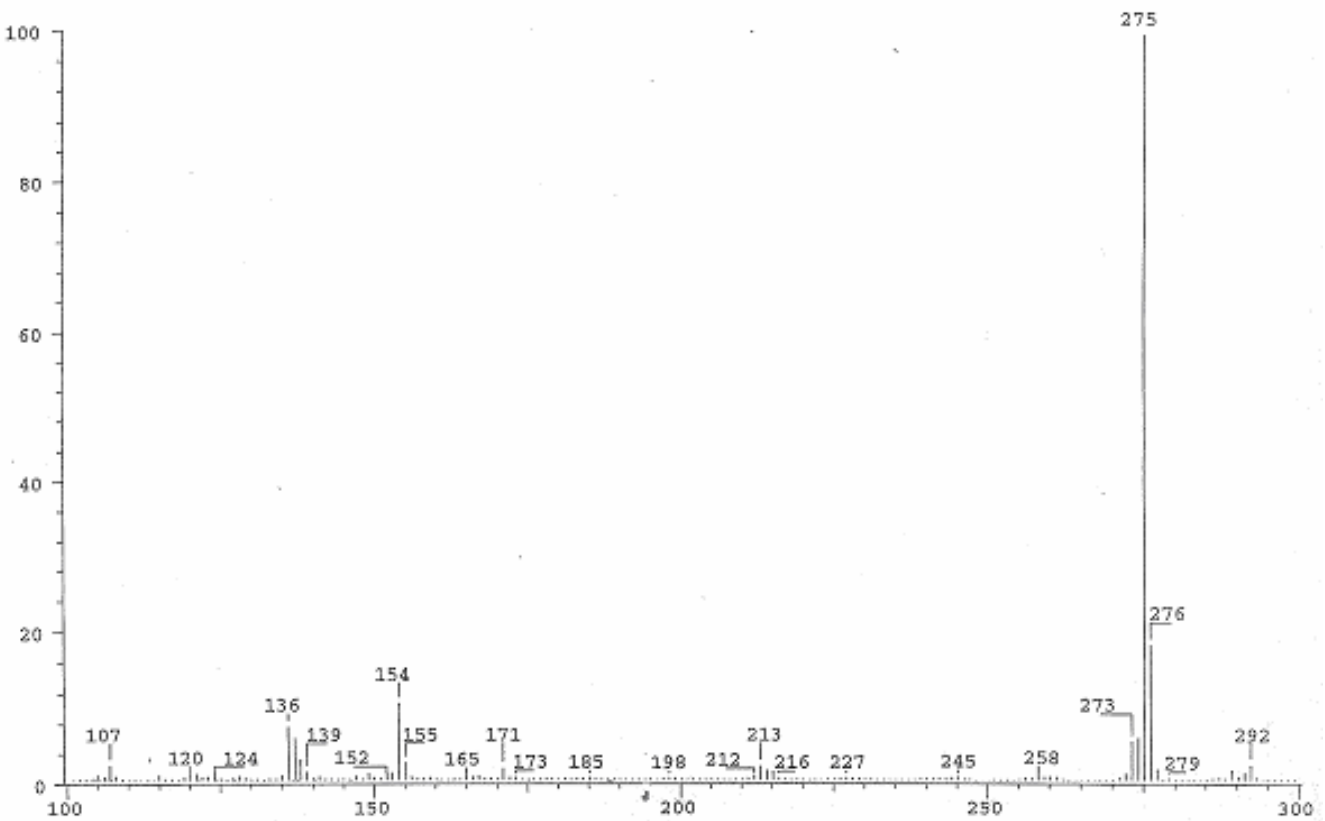

Figure 7. FAB spectrum of $\mathrm{N}-\mathrm{CD}_{3}$-dextromethorphan 5 hydrochloride salt. 
The FAB MS spectrum of $\mathrm{N}-\mathrm{CD}_{3}$-dextromethorphan 5 base was not consistent with the above mentioned $\mathrm{FAB}$ results of the corresponding salt. The quaternary ion $=\mathrm{N}^{+}\left(-\mathrm{CD}_{3}\right)_{2}, \mathrm{C}_{3}{ }^{+}$ $=292$ could be observed beside the characteristic $\mathrm{m} / \mathrm{z} \mathrm{M}_{1} \mathrm{H}^{+}=275$ and $\mathrm{M}_{1}-\mathrm{H}^{+}=273$ peaks and the peak of the $\mathrm{M}_{2} \mathrm{H}^{+}=272$ increased significantly $(\sim 20 \%$; Figure 8$)$.

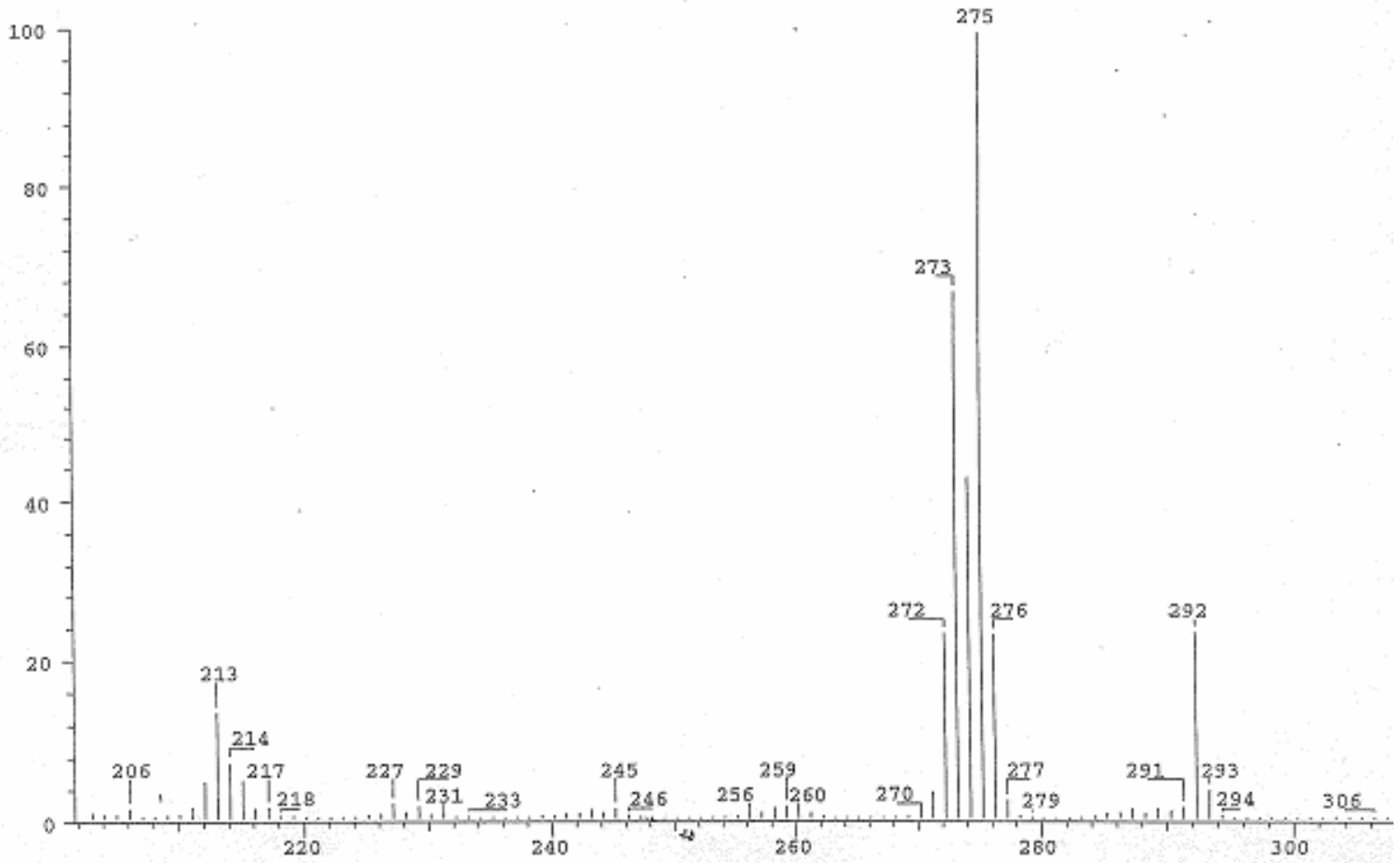

Figure 8. FAB MS spectra of the $\mathrm{N}-\mathrm{CD}_{3}$-dextromethorphan base.

The EI spectrum of $\mathrm{N}-\mathrm{CD}_{3}$-dextromethorphan 5 base was characterized by an intense molecular ion peak $\mathrm{M}_{1}=274$, which was accompanied by the molecular ion peak of the $\mathrm{N}^{-} \mathrm{CH}_{3}$ derivative as a contamination $\mathrm{M}_{2}=271(\sim 2-3 \%$; Figure 9$)$. In the case of $\mathrm{N}_{-} \mathrm{CD}_{3}$-dextrorphan 6 analogue the quantity of the dextrorphan 2 contamination was established in a similar way by MS spectroscopy. 


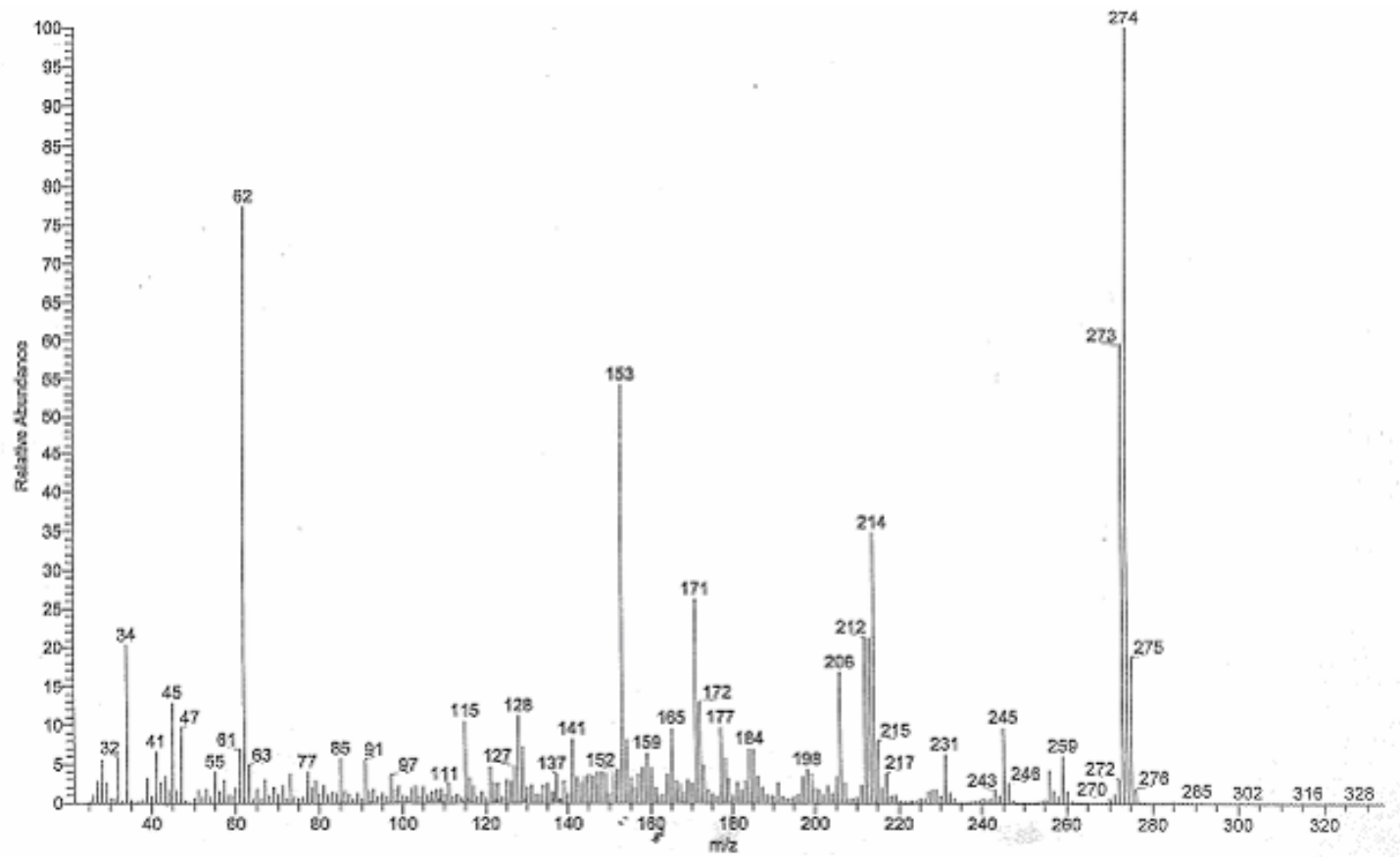

Figure 9. EI spectrum of $\mathrm{N}-\mathrm{CD}_{3}$-dextromethorphan 5 base.

\section{Conclusions}

For pharmacokinetic studies two new deuterated compounds, $\mathrm{N}-\mathrm{CD}_{3}$-dextromethorphan 5 and $\mathrm{N}-\mathrm{CD}_{3}$-dextrorphan 6 with isotopic enrichment between 97-98 \% were synthesized.

\section{Experimental Section}

General Procedures. ${ }^{1} \mathrm{H}$ NMR spectra (499.97 MHz) were recorded on a Varian Inova-500 spectrometer at $30^{\circ} \mathrm{C}$ using an $\mathrm{HCN}$ indirect detection triple resonance probe. Deuterated solvents 99.95 atom \% were purchased from Merck Gmbh ${ }^{\circledR}$. Proton chemical shifts are referenced to the residual solvent signal $\left(\delta_{\mathrm{DMSO}}=2.50 \mathrm{ppm}, \delta_{\mathrm{C} 5 \mathrm{D} 5 \mathrm{~N}}=7.19 \mathrm{ppm}\right)$. Four scans were recorded and 20 second relaxation delay was applied to allow proper quantitation via the NMR integrals. Mass spectra were measured on a Finnigan MAT 95 XP instrument. A Fisons MD 800 instrument for GC-MS and a Thermo Separation Products instrument (UV 3000HR, P4000, AS1000, SN4000) for HPLC analysis were used. 


\section{1,3,4,9,10,10a-Hexahydro-6-methoxy-2H-10,4a-(iminoethano)phenantrene-11-carboxylic acid 2,2,2-trichloroethyl ester (7)}

Dextromethorphan hydrobromide monohydrate $(5.56 \mathrm{~g}, 15 \mathrm{mmoles})$ was dissolved in $60 \mathrm{ml}$ of chloroform and a solution of $1.2 \mathrm{~g}$ sodium hydroxide in $60 \mathrm{~mL}$ of water. After stirring for 1 hour the organic layer was separated, dried (sodium sulfate), and evaporated in vacuum. The obtained oil was refluxed in $50 \mathrm{ml}$ of toluene with $2.4 \mathrm{ml}$ of 2,2,2-trichloroethyl chloroformate for 4 hours. The reaction was checked by TLC (Kieselgel 60, chloroform-methanol $=95: 5, R_{f}=0.7$ ). After completion of the reaction the solvent was evaporated in vacuum. The residual oil was purified on a Kieselgel $60(0.063-0.200)$ column (eluent: chloroform-methanol $=95: 5)$, giving 6.0 g oil (13.86 mmoles, yield: $92.42 \%) .{ }^{1} \mathrm{H}-\mathrm{NMR}\left(300 \mathrm{MHz}, \mathrm{CDCl}_{3}, 30^{\circ} \mathrm{C}\right): \delta 0.94-1.12(\mathrm{~m}$, $1 \mathrm{H}, \mathrm{CH}) ; 1.16-1.72(\mathrm{~m}, 9 \mathrm{H}, \mathrm{CH}) ; 2.26-2.37(\mathrm{~m}, 1 \mathrm{H}, \mathrm{CH}) ; 2.54-2.76(\mathrm{~m}, 2 \mathrm{H}, \mathrm{CH}) ; 3.06(\mathrm{dd}, 1 \mathrm{H}$, $\mathrm{J}=17.7$ and $6.0 \mathrm{~Hz}, \mathrm{CH}) ; 3.72\left(\mathrm{~s}, 3 \mathrm{H}, \mathrm{OCH}_{3}\right) ; 3.79-3.92(\mathrm{~m}, 1 \mathrm{H}, \mathrm{CH}), 4.32(\mathrm{dd}, 1 \mathrm{H}, \mathrm{J}=4.6$ and 4.4 $\mathrm{Hz}, \mathrm{CH})$; amide rotamers: [ 4.65 and $4.71\left(\mathrm{~d}, 1 \mathrm{H}, \mathrm{J}=12.3 \mathrm{~Hz}, \mathrm{CH}_{2}\right)$ and 4.66 and $4.79(\mathrm{~d}, 1 \mathrm{H}$, $\left.\mathrm{J}=12.0 \mathrm{~Hz}, \mathrm{CH}_{2}\right)$ ]; $6.66(\mathrm{dd}, 1 \mathrm{H}, \mathrm{J}=8.4$ and $3.0 \mathrm{~Hz}, \mathrm{Ar}) ; 6.77(\mathrm{~d}, 1 \mathrm{H}, \mathrm{J}=3.0 \mathrm{~Hz}, \mathrm{Ar}$ ); amide rotamers: [6.95 and $6.96(\mathrm{~d}, 1 \mathrm{H}, \mathrm{J}=8.4 \mathrm{~Hz}, \mathrm{Ar})$ ]; GC-MS: $98.0 \%$; MS: EI m/e $431\left(\mathrm{M}^{+}, 6.7 \%\right)$, $213(100.0 \%)$.

\section{3-Methoxymorphinan tetraacetatozincate (8)}

The above prepared trichloroethyl ester derivative 7 (6.0 g, 13.86 mmoles) was dissolved in 57.5 $\mathrm{ml}$ of acetic acid and $5.89 \mathrm{ml}$ of distilled water, to which $2.9 \mathrm{~g}$ of powered zinc was added. After 50 minutes stirring the completeness of the reaction was checked by TLC. Further $2.9 \mathrm{~g}$ of zinc was added to the reaction mixture. After 1 hour stirring the reaction mixture was filtered. The obtained white powder was washed three times with ether. Yield: $10.7 \mathrm{~g}$ crude product; mp 161$164^{\circ} \mathrm{C} ;{ }^{1} \mathrm{H}-\mathrm{NMR}\left(300 \mathrm{MHz}, \mathrm{CDCl}_{3}, 30^{\circ} \mathrm{C}\right): \delta 0.80-1.00(\mathrm{~m}, 1 \mathrm{H}, \mathrm{CH}) ; 1.08-1.42(\mathrm{~m}, 5 \mathrm{H}, \mathrm{CH})$; $1.43-1.53$ (m, $1 \mathrm{H}, \mathrm{CH}) ; 1.54-1.76(\mathrm{~m}, 2 \mathrm{H}, \mathrm{CH}) ; 1.82$ (s, 6H, $\left.\mathrm{CH}_{3} \mathrm{COO}^{-}\right), 1.80-1.89$ (m, $\left.1 \mathrm{H}, \mathrm{CH}\right)$; 2.32-2.48 (m,2H, CH); 2.74-3.07 (m, 3H, CH); 3.39-3.46 (m, br, $1 \mathrm{H}, \mathrm{CH}) ; 3.72\left(\mathrm{~s}, 3 \mathrm{H}, \mathrm{OCH}_{3}\right)$; 3.00-5.00 (s, vbr, $3 \mathrm{H}, \mathrm{NH}^{+}$and $\mathrm{H}_{2} \mathrm{O}$ ), 6.75-6.82 (m, 2H, Ar); 7.07 (d, $\left.1 \mathrm{H}, \mathrm{J}=8.4 \mathrm{~Hz}, \mathrm{Ar}\right)$; FABMS: $\mathrm{C}^{+}{ }_{1}=258$.

\section{$\mathrm{N}$-Desmethyl-dextromethorphan (4)}

The above prepared $10.7 \mathrm{~g}$ of 3-methoxymorphinan tetraacetatozincate 8 was partitioned between $300 \mathrm{ml}$ of chloroform and $100 \mathrm{ml}$ of $1 \mathrm{~N}$ sodium hydroxide solution in water. The organic layer was separated, dried (sodium sulfate), evaporated in vacuum to yield: $3.1 \mathrm{~g}$ (12.04 mmoles, yield: 86.9\%); GC-MS: 99.45\%; ${ }^{1} \mathrm{H}-\mathrm{NMR}\left(300 \mathrm{MHz}, \mathrm{CDCl}_{3}, 30^{\circ} \mathrm{C}\right): \delta 1.00-1.12(\mathrm{~m}$, $1 \mathrm{H}, \mathrm{CH}) ; 1.24-1.45$ (m, 5H, CH); 1.46-1.69 (m, 3H, CH); 1.70-1.80 (m, 1H, CH); 2.14 (s, br, 1H, $\mathrm{NH}) ; 2.26-2.35(\mathrm{~m}, 1 \mathrm{H}, \mathrm{CH}) ; 2.55-2.76(\mathrm{~m}, 3 \mathrm{H}, \mathrm{CH}) ; 3.02-3.16(\mathrm{~m}, 3 \mathrm{H}, \mathrm{CH}) ; 3.79(\mathrm{~s}, 3 \mathrm{H}$, $\left.\mathrm{OCH}_{3}\right) ; 6.70(\mathrm{dd}, 1 \mathrm{H}, \mathrm{J}=8.4$ and $2.7 \mathrm{~Hz}, \mathrm{Ar}) ; 6.81(\mathrm{~d}, 1 \mathrm{H}, \mathrm{J}=2.7 \mathrm{~Hz}, \mathrm{Ar}) ; 7.03(\mathrm{~d}, 1 \mathrm{H}, \mathrm{J}=8.4 \mathrm{~Hz}$, Ar); MS EI m/e 257 (M+1 100.0\%), 228 (M-29), 214 (M-43), 212 (M-45), 171 (M-(2x43)).

\section{$\mathrm{N}$-CD $\mathrm{CD}_{3}$-Dextromethorphan (5)}

To the solution of the above prepared N-desmethyl-dextromethorphan 4 (3.1 g, 12.04 mmoles) in $265 \mathrm{ml}$ of tetrahydrofuran $10.1 \mathrm{~g}$ of sodium hydride (60\% dispersion in mineral oil) was added. After 20 minutes stirring $1 \mathrm{ml}(2.329 \mathrm{~g}=16.067$ mmoles $)$ of iodomethane- $\mathrm{d}_{3}$ was dropped into 
the reaction mixture. The reaction was controlled by TLC. After 1 hour stirring at $\mathrm{rt}$. the reaction mixture was poured into $180 \mathrm{ml}$ of distilled water, which was extracted three times with $100 \mathrm{ml}$ of diethyl ether. The organic layer was separated, dried (sodium sulfate), and evaporated in vacuum. The residue was crystallized in $n$-hexane. (Yield: $1.7 \mathrm{~g}, 6.195$ mmoles, $51.5 \%$; mp 98$\left.103^{\circ} \mathrm{C}\right) .{ }^{1} \mathrm{H}-\mathrm{NMR}\left(300 \mathrm{MHz}, \mathrm{DMSO}, 30^{\circ} \mathrm{C}\right): \delta$ 0.93-1.07 (m, 1H, CH); 1.11-1.40 (m, 5H, CH); 1.42-1.52 (m, 1H, CH); 1.53-1.66 (m, 2H, CH); 1.66-1.75 (m, 1H, CH); 1.93 (ddd,1H, J=12.3, 12.2 and $3.3 \mathrm{~Hz}, \mathrm{CH}) ; 2.25-2.38(\mathrm{~m}, 2 \mathrm{H}, \mathrm{CH}) ; 2.48(\mathrm{dd}, 1 \mathrm{H}, \mathrm{J}=17.7$ and $5.7 \mathrm{~Hz}, \mathrm{CH}) ; 2.68$ (dd, $1 \mathrm{H}, \mathrm{J}=5.7$ and $3.3 \mathrm{~Hz}, \mathrm{CH}) ; 2.90(\mathrm{~d}, 1 \mathrm{H}, \mathrm{J}=17.7 \mathrm{~Hz}, \mathrm{CH}) ; 3.70\left(\mathrm{~s}, 3 \mathrm{H}, \mathrm{OCH}_{3}\right) ; 6.65(\mathrm{dd}, 1 \mathrm{H}$, $\mathrm{J}=8.4$ and $2.7 \mathrm{~Hz}, \mathrm{Ar}) ; 6.72(\mathrm{~d}, 1 \mathrm{H}, \mathrm{J}=2.7 \mathrm{~Hz}, \mathrm{Ar}) ; 7.00$ (d, 1H, J=8.4 Hz, Ar); 8.85 (s, br, 1H, $\mathrm{OH})$; FAB-MS m/z $275\left(\mathrm{M}_{1} \mathrm{H}^{+}\right)$; MS EI m/z $274\left(\mathrm{M}_{1}{ }^{+}, 100.0 \%\right), 271\left(\mathrm{M}_{2}{ }^{+}, \sim 2-3 \%\right)$.

$\mathrm{N}$-CD $\mathbf{C D}_{3}$-Dextromethorphan (5) hydrochloride salt. $\mathrm{N}-\mathrm{CD}_{3}$-dextromethorphan $5(1.7 \mathrm{~g})$ was dissolved in ethyl acetate-methanol mixture and was acidified with $\mathrm{HCl}$ in ethyl acetate to $\mathrm{p}_{\mathrm{H}}=2$, $n$-hexane was added to the solution. The obtained crystals were filtered. Yield: $1.1 \mathrm{~g}(3.54$ mmoles, 57.1\%); mp 121-123 ${ }^{\circ} \mathrm{C}$. ${ }^{1} \mathrm{H}-\mathrm{NMR}$ (see Figure 4) $\left(300 \mathrm{MHz}, \mathrm{DMSO}, 30^{\circ} \mathrm{C}\right)$ : sum of protonated epimers: $\delta$ 0.87-1.03 (m, 1H, CH); 1.04-1.67 (m, 7H, CH); 1.88-2.05 (m, 1H, CH); 2.12-2.27 (m, 1H, CH); 2.33-2.49 (m, 2H, CH); 2.90-3.19 (m, 3H, CH); 3.50-3.56 (m, 1H, CH); $3.73\left(\mathrm{~s}, 3 \mathrm{H}, \mathrm{OCH}_{3}\right)$; 6.79-6.85 (m, 2H, Ar); 7.09-7.16 (m, 1H, Ar); 11.18 and $11.22\left(\mathrm{~s}, 1 \mathrm{H}, \mathrm{NH}^{+}\right)$; MS FAB m/z $275\left(\mathrm{M}_{1} \mathrm{H}^{+}, 100.0 \%\right), 272\left(\mathrm{M}_{2} \mathrm{H}^{+}, 2 \%\right)$; GC-MS: 98.8\%; HPLC: 99.4\% (220 nm); isotopic enrichment 97 atom \% D.

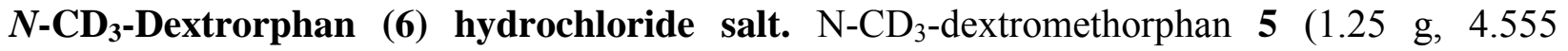
mmoles) was heated in $50 \mathrm{ml}$ of hydrobromic acid $(48 \%)$ at $110{ }^{\circ} \mathrm{C}$ for two hours. After cooling $125 \mathrm{ml}$ of chloroform and $40 \mathrm{ml}$ of ammonium hydroxide solution (25\%) were added dropwise to the reaction mixture $\left(\mathrm{p}_{\mathrm{H}}=9\right)$. The organic layer was separated, dried (sodium sulfate), and evaporated in vacuum. The residue was dissolved in ethanol - ethyl acetate mixture. Acidifying the solution with $\mathrm{HCl}$ in ethyl acetate to $\mathrm{p}_{\mathrm{H}}=2$, the obtained $\mathrm{HCl}$ salt of 6 was crystallized. Yield: $1.0 \mathrm{~g}$ (3.369 mmoles, $74.0 \%$ ); mp 122-127 ${ }^{\circ} \mathrm{C} .{ }^{1} \mathrm{H}-\mathrm{NMR}$ (see Figure 5) (300 MHz, DMSO, $\left.30^{\circ} \mathrm{C}\right)$ : sum of protonated epimers: $\delta$ 0.88-1.13 $(\mathrm{m}, 1 \mathrm{H}, \mathrm{CH}) ; 1.10-1.67(\mathrm{~m}, 7 \mathrm{H}, \mathrm{CH})$; 1.82-1.95 (m, 1H, CH); 2.09-2.19 (m, 1H, CH); 2.28-2.37 (m, 1H, CH); 2.40-2.49 (m, 1H, CH); 2.84-3.19 (m, 3H, CH); 3.50-3.56 (m, 1H, CH); 6.64 (dd, 1H, J=8.4 and 2.4 Hz, Ar); $6.71(\mathrm{~d}, 1 \mathrm{H}$, $\mathrm{J}=2.4 \mathrm{~Hz}, \operatorname{Ar}) ; 7.00$ (d, 1H, J=8.4 Hz, Ar); 9.22 (s, br, 1H, $-\mathrm{OH}) ; 10.69$ and $10.71\left(\mathrm{~s}, 1 \mathrm{H}, \mathrm{NH}^{+}\right)$; MS: EI m/e $260\left(\mathrm{M}_{1}{ }^{+}, 100.0 \%\right), 257\left(\mathrm{M}_{2}{ }^{+}, \sim 2-3 \%\right)$; GC-MS: $97.3 \%$; HPLC: $99.5 \%$ (220 nm); isotopic enrichment 97 atom \% D.

\section{Acknowledgements}

We are grateful to Dr. Béla Hegedüs and Ms. Erika Szíki for the IR, to Dr. Attila Rill for the HPLC measurements, Dr. Gábor Tárkányi, Mr. Attila Fürjes and Mrs. Margit Melegh for NMR assistance and to István Abrudbányay and Gabriella Barna for the technical help. 


\section{References and Notes}

1. Martindale The Complete Drug Reference, 34 Edn., Sweetman S.C., Ed., London: Pharmaceutical Press: London, 2005.

2. Tortella, F. C.; Pellicano, M.; Bowery, N. G. Trends Pharmcol. Sci. 1989, 10, 501.

3. Bonucelli, U.; Del Donto, P.; Piccini, P.; Benge, F.; Corsini, G. U.; Muratorio, A. Lancet 1992, 340, 53.

4. Albers, G. W.; Atkinson, R. P.; Kelley, R. E.; Rosenbaum, D.M. Stroke 1995, $26,254$.

5. Tihanyi, K.; Kocsis, P.; Németh, Gy.; Tarnawa, I.; Dalmadi, B. WO04089352 A2, 2004.

6. Eichhold, T. H.; Quijano, M.; Seibel, W. L.; Cruze, Ch. A.; Dobson, R. L. M.; Wehmeyer K. R. J. Chromatography B, 1997, 698, 147.

7. Von Braun, J. Chem. Ber. 1909, 42, 2035.

8. Ripper, J. A.; Tiekink, E. R. T.; Scammels, P. J. Bioorg. Med. Chem. Letters 2001, 11, 443.

9. Anastasia, L.; Cighetti, G.; Allevi, P. J. Chem. Soc., Perkin Trans. I 2001, 2398.

10. Thavaneswaran, S.; Scammels, P. J. Bioorg. Med. Chem. Letters 2006, 16, 2688.

11. Csutoras, Cs.; Zhang, A.; Bidlack, J. M.; Neumeyer, J. L. Bioorg. Med. Chem. 2004, 12, 2687.

12. Kraiss, G.; Nádor, K. Tetrahedron Lett. 1971, 57.

13. Cooley, J. H.; Evain,E. J. Synthesis 1989, 1 and references cited therein.

14. Abdel-Monem, M. M., Portoghese, P. S. J. Med. Chem. 1972, 15, 208.

15. Peet, N. P. J. Pharm. Sci. 1980, 1447.

16. Comprehensive Organic Transformations $2^{\text {nd }}$ Edn, Larock R. C. Ed., Wiley-VCH: New York, 1999; pp 779-784.

17. Hemmer, R.; Lürken, W. In Methoden der Organischen Chemie (Houben-Weyl) Band E16d Organische Stickstoff-verbindungen IV D. Klamann Georg Thieme Verlag: Stuttgart, New York 1992; pp 665-672.

18. Corrodi, H.; Hellerbach, J.;Züst; A., Hardegger, E.; Schnider, O. Helv. Chim. Acta 1959, 18, 212.

19. Kim, H.-C.; Nabeshima, T.; Jhoo, W.-K.; Ko, K. H.; Kim, W.-K.; Shin, E.-J.; Cho, M.; Lee, P. H. Bioorg. Med. Chem. Letters 2001, 11, 1651. 